\title{
Utilization and Partition of Dietary Nitrogen in Dairy Cows Fed Grass Silage-Based Diets
}

\author{
P. Huhtanen,${ }^{*} \dagger^{1}$ J. I. Nousiainen, ${ }^{*}$ M. Rinne, ${ }^{*}$ K. Kytölä, ${ }^{*}$ and H. Khalili ${ }^{*}$ \\ *MTT Agrifood Research Finland, Animal Production Research, FIN-31600 Jokioinen, Finland \\ †Department of Animal Science, Cornell University, Ithaca, NY 14850
}

\begin{abstract}
Data from 207 production trials (998 treatment means) were used to study the effects of animal and dietary characteristics on the efficiency of $\mathrm{N}$ utilization for milk protein production, and on fecal $\mathrm{N}$, urinary $\mathrm{N}$, and total manure $\mathrm{N}$ output. The average efficiency of transferring dietary $\mathrm{N}$ to milk $\mathrm{N}$ (MNE; milk N/N intake) was $277(\mathrm{SD}=36.0) \mathrm{g} / \mathrm{kg}$. Nitrogen efficiency was poorly related to milk yield. Dietary concentrations of crude protein (CP) and protein balance in the rumen (PBV) were the best single predictors of MNE. Dietary $\mathrm{CP}$ concentration explained variation in $\mathrm{MNE}$ better than did $\mathrm{N}$ intake. Bivariate models with PBV or metabolizable protein (MP) explained the variation better than $\mathrm{CP}$ alone. The effects of protein feeding parameters on MNE were consistent among data subsets from studies investigating the effects of the amount and protein concentration of concentrate supplement, silage digestibility, silage fermentation quality, or substitution of grass silage with legume silage. The model with total dry matter and $\mathrm{N}$ intakes as independent variables explained fecal, urinary, and total manure $\mathrm{N}$ output more precisely than $\mathrm{N}$ intake alone. The model of fecal $\mathrm{N}$ output suggested that the true digestibility of dietary $\mathrm{N}$ was 0.91 , and that metabolic and endogenous $\mathrm{N}$ was the major component in fecal $\mathrm{N}$. The proportion of urine $\mathrm{N}$ in manure $\mathrm{N}$ was strongly related to dietary $\mathrm{CP}$ concentration. Including the concentration of dietary carbohydrates only slightly improved the models, indicating that the most effective strategy to improve $\mathrm{MNE}$ and to decrease $\mathrm{N}$ losses in manure, especially in urine, is to avoid feeding diets with excessively high CP concentration and especially excess ruminally degradable CP.
\end{abstract}

Key words: $\mathrm{N}$ utilization, dairy cow, grass silage, protein

Received March 14, 2008.

Accepted May 18, 2008.

${ }^{1}$ Corresponding author: pjh87@cornell.edu

\section{INTRODUCTION}

Dairy farming is known to contribute to both atmospheric and hydrospheric pollution (Tamminga, 1992). In spite of improved diet formulation systems and genetic potential of the cows, $\mathrm{N}$ efficiency for milk protein production (MNE) has remained relatively low. Small improvements in the efficiency of nutrient utilization by dairy cows have been counterbalanced by increased external inputs of concentrate and fertilizer $\mathrm{N}$ to dairy farms, and consequently the efficiency of $\mathrm{N}$ use in the farming systems has reduced. For example, in the Netherlands, the overall $\mathrm{N}$ efficiency of dairy farming systems decreased from 0.40 in the 1950 s to less than 0.20 in the 1980s (Van Keulen et al., 1996). However, recent data (Groot et al., 2006) demonstrate that $\mathrm{N}$ efficiency in dairy farm increased from 0.20 to 0.30 in 5 yr by reducing external inputs (mainly fertilizers).

To keep the soil-plant-animal system ecologically sustainable, the 3 components should be balanced with each other so that losses of $\mathrm{N}$ and other nutrients are minimized (Tamminga, 1996). Balanced fertilizer and concentrate $\mathrm{N}$ imports to the farm and improved efficiency of $\mathrm{N}$ uptake from the soil are more effective strategies in reducing $\mathrm{N}$ losses from a dairy farm to the environment than is improving the $\mathrm{N}$ efficiency in the animal (Van Bruchem et al., 1999; Virtanen and Nousiainen, 2005). However, it is important to understand the effects of diet characteristics on MNE, manure $\mathrm{N}$ output, and especially distribution between fecal and urinary $\mathrm{N}$, because urinary $\mathrm{N}$ is much more vulnerable to evaporative and leaching losses. This information is essential in the models predicting nutrient surplus from whole production systems.

Several analyses of factors influencing manure $\mathrm{N}$ output have been published, but most have been based on individual cow data (Castillo et al., 2000; Kebreab et al., 2001; Nennich et al., 2005; Yan et al., 2006). Animal and dietary factors can be confounded in models based on individual cow data, which can result in biased estimates of the effects of nutritional factors on MNE and manure $\mathrm{N}$ output. Our objectives were to conduct a meta-analysis of data from milk production 
trials conducted in dairy cows to 1) quantify the effects of animal and dietary factors on MNE, 2) produce equations to predict fecal and urinary $\mathrm{N}$ output, and 3) discuss possibilities to reduce $\mathrm{N}$ emissions at the farm level. The data are based mainly on grass silage-based diets typical for northern European countries.

\section{MATERIALS AND METHODS}

\section{Experimental Data}

The data analyzed in this study were collected from 207 lactation trials including 998 treatment means. The studies were conducted from 1979 to 2005. One treatment mean was based on 11.2 cows. Grass silage was the main forage source, but for 82 and 38 diets, grass silage was partly or completely replaced with legume (mainly red clover) and whole-crop silages (barley, wheat, corn), respectively. The forages were fed ad libitum in all trials and concentrates were fed on a flat-rate basis irrespective of milk yield. The main ingredients in concentrates were barley, oats, molassed sugarbeet pulp, and by-products from the milling and ethanol industry. Rapeseed meal, soybean meal, and fish meal were the main protein supplements. All variables showed a wide range of variation. The following parameters describing diet composition were used for statistical analyses: dietary concentration $(\mathrm{g} / \mathrm{kg}$ of $\mathrm{DM})$ of $\mathrm{CP}(6.25 \times \mathrm{N})$, MP estimated as amino acids absorbed from the small intestine, protein balance in the rumen (PBV), NDF, RDP, RUP, starch, NFC, lactic acid (LA), and VFA. Fermentation acids were analyzed from silages, ensiled cereal grains, and from some wet by-product feeds.

Dietary concentrations of MP and PBV were computed as described in the Finnish feed tables (MTT, 2006). Microbial MP $(\mathrm{g} / \mathrm{kg}$ of DM) was calculated as $0.179 \times$ [digestible crude carbohydrates ( $\mathrm{g} / \mathrm{kg}$ of $\mathrm{DM})+$ effective protein degradability $(\mathbf{E P D}) \times \mathrm{CP}(\mathrm{g} / \mathrm{kg}$ of $\mathrm{DM})]$ $\times 0.70 \times 0.85$, where the coefficients are the efficiency of microbial protein synthesis (0.179), proportion of amino acid $\mathrm{N}$ in microbial $\mathrm{N}$ (0.70), and digestibility of microbial protein (0.85). Digestible carbohydrates were calculated as the sum of digestible crude fiber and nitrogen-free extracts determined at maintenance level of feeding. Tabulated values (MTT, 2006) for EPD were used to compute RDP and RUP. The EDP values were derived from in situ studies and from duodenal flow data. Passage rate values of $0.02 / \mathrm{h}$ and 0.03 to $0.04 / \mathrm{h}$ for forages and concentrates were used to compute EPD. Ruminal protein balance was the difference between the RDP supply and microbial requirements of RDP; that is, it is an estimate of rumen $\mathrm{N}$ losses. It was expressed in grams per day or grams per kilogram of DMI. The supply of RDP (g/d) was calculated as EPD $\times$ CP intake (g/d) and microbial CP requirement $(\mathrm{g} / \mathrm{kg})$ as $0.179 \times \mathrm{DMI}(\mathrm{kg} / \mathrm{d}) \times$ [digestible carbohydrates $(\mathrm{g} / \mathrm{kg}$ of $\mathrm{DM})+\mathrm{EPD} \times \mathrm{CP}(\mathrm{g} / \mathrm{kg}$ of $\mathrm{DM})]$. Apparent diet digestibility was determined in 95 studies (509 diets) by total fecal collection ( $\mathrm{n}=160)$ or by using acid insoluble ash (Van Keulen and Young, 1977) as an internal marker $(\mathrm{n}=349)$. The NFC concentration was calculated as OM - CP - ether extract - NDF. The concentration of ME was estimated using feed table values (MTT, 2006) for concentrates. Silage-digestible $\mathrm{OM}$ and subsequently $\mathrm{ME}$ concentration were estimated in vivo in sheep fed at maintenance level $(\mathrm{n}=467)$, by in vitro methods using rumen fluid (Tilley and Terry, 1963; $\mathrm{n}=114$ ), or by using the pepsin-cellulase method (Nousiainen et al., $2003 ; \mathrm{n}=224)$, or by some other laboratory method ( $\mathrm{n}=$ 183). The same method was used within a study.

The following animal measurements were included in the data: silage, concentrate and total DM intake, yield of milk, ECM, milk CP $(6.38 \times$ total milk N), fat and lactose, BW, and average DIM during experiment. Milk urea $\mathrm{N}$ was analyzed in 91 trials (495 diets) from composite samples of a.m. and p.m. milkings as described by Nousiainen et al. (2004). Intake of nutrients was calculated as DMI $\times$ respective nutrient concentration. The apparent MNE was estimated as milk N/N intake. Fecal $\mathrm{N}$ output was calculated as $(1-\mathrm{N}$ digestibility) $\times \mathrm{N}$ intake. Urinary $\mathrm{N}$ output (unaccounted $\mathrm{N}$ ) was estimated as $\mathrm{N}$ intake - milk $\mathrm{N}$ yield - fecal $\mathrm{N}$ output, assuming that $\mathrm{N}$ retention was zero.

The relationships between MNE and animal or dietary parameters were estimated from the whole data set (207 comparisons, 998 diets) or from 5 data subsets, in which data was divided into studies comparing effects of the level of concentrate supplementation (87 comparisons, 217 diets), CP concentration of the concentrate supplement (127 comparisons, 336 diets), silage digestibility influenced by the stage of maturity at harvest (24 comparisons, 81 diets), silage fermentation quality influenced by the type rate of additive applications (86 comparisons, 240 diets), and replacement of grass silage with legume silages (18 comparisons, 53 diets).

\section{Statistical Analysis}

Because part of the variation in $\mathrm{N}$ utilization in milk production can result from differences in, for example, the stage of lactation, genetic potential of the cows, and feeding strategies, it is important to exclude this variation when nutritional factors were investigated. Therefore, the relationships between $\mathrm{N}$ utilization and animal or dietary measurements within an experiment were investigated using the MIXED procedure of SAS 
(Littell et al., 1996) using the model $\mathrm{Y}=\mathrm{B}_{0}+\mathrm{B}_{1} \mathrm{X}_{1 \mathrm{ij}}+$ $\mathrm{b}_{0}+\mathrm{b}_{1} \mathrm{X}_{1 \mathrm{ij}}+\mathrm{B}_{2} \mathrm{X}_{2 \mathrm{ij}}+\mathrm{B}_{3} \mathrm{X}_{3 \mathrm{ij}}+\mathrm{e}_{\mathrm{ij}}$, where $\mathrm{Y}$ is dependent variable, $\mathrm{B}_{0}+\mathrm{B}_{1} \mathrm{X}_{1 \mathrm{ij}+} \mathrm{B}_{2} \mathrm{X}_{2 \mathrm{ij}}+\mathrm{B}_{3} \mathrm{X}_{3 \mathrm{ij}}$ is the fixed part of the model; $b_{0}, b_{1} X_{1 i j}$, and $\mathrm{e}_{\mathrm{ij}}$ are the random part of the model; $i=1 \ldots 207$ studies; and $j=1 . . . n_{i}$ values.

In the models with 1 continuous independent variable an unstructured variance-covariance matrix for the intercepts and slopes were used. Using 2 or more continuous random independent variables can result in an overparameterized model and therefore only the random slope for the first independent parameter was used. In some cases, the models with 1 independent variable did not converge when the slope was random. In those cases, all the alternative models predicting the same dependent variable were estimated using only a random intercept statement. Further details of the mixed model methodology are reported in a review by St-Pierre (2001). The models were constructed by comparing first the single parameter models and then including other biologically relevant variables with the best single parameter. The goodness of fit of the models was compared according to Akaike's information criteria (AIC). The model with the smallest AIC value is likely to be the most correct. Residual mean square errors (RMSE) were calculated for the values adjusted for the random study effect.

\section{RESULTS}

\section{Data Characterization}

Parameters of feed and nutrient intake, diet composition, digestibility, and milk production are shown in Table 1. There was a large range in dietary CP concentration (from 101 to $252 \mathrm{~g} / \mathrm{kg}$ of DM) and PBV (from -51 to $82 \mathrm{~g} / \mathrm{kg}$ of DM). The cows were on average 103 DIM; that is, during the lactation phase when energy balance is generally close to zero. The average MNE, expressed as milk $\mathrm{N}$ output/ $\mathrm{N}$ intake $(\mathrm{g} / \mathrm{kg})$, was 277 (SD: 36.0; range: 164 to 402).

Large variation in the proportion of concentrate, dietary concentrations of starch, and NDF also indicated that the data included a wide range of diets. The variation in production parameters reflected differences in diet composition, genetic production potential of the cows, stage of lactation, and different age distribution of the cows (from only primiparous to only multiparous) used in different studies.

\section{Effect of Milk Yield on N Efficiency}

The effects of milk yield on the apparent $\mathrm{N}$ efficiency are shown in Figure 1. When analyzed with simple regression model, milk yield was positively associated with MNE, but it explained only $14 \%$ of the variation.
With the mixed model analysis, milk yield did not have a significant effect on MNE; that is, within a study the feeding strategies increasing milk yield did not affect MNE. The regression coefficient of milk yield was rather similar between simple and mixed models (3.4 vs. $2.9 \mathrm{~g} / \mathrm{kg}$ per $\mathrm{kg}$ ) when dietary $\mathrm{CP}$ concentration was included in the bivariate model with milk yield (models not shown). The stage of lactation had a strong influence on the apparent MNE, but in the mixed model analysis, DIM had no effect, probably because the cows were in the same stage of lactation within a study.

\section{Relationships Between N Efficiency and Dietary Protein}

Linear and multiple prediction equations of MNE are presented in Table 2. The model with CP intake as an independent variable did not converge when both the intercept and slope were random, and therefore in all models only the intercept was kept random. Increased protein intake, irrespective of which parameter $(\mathrm{CP}$, RDP, RUP, and MP) was used, was negatively related to MNE, with PBV intake being the best single predictor and MP the worst according to AIC. Addition of DMI to the model with CP intake improved the model markedly compared with CP intake alone (Table 2). The coefficient of DMI was positive indicating that the effect of increased CP intake on MNE was strongly dependent on how CP intake was increased (increased dietary CP concentration vs. DM intake). The best model based on RMSE and AIC was a bivariate model with PBV and MP intake as independent variables.

Milk $\mathrm{N}$ efficiency decreased as dietary $\mathrm{CP}$ concentration increased (Table 3). Including the quadratic effect improved the model according to the AIC value. Expressing CP as a ratio to ME rather than on a DM basis improved the model. Rumen PBV was a better predictor of MNE than CP, and the model was further improved when the MP concentration was used with PBV. The negative regression coefficient of PBV on MNE was much greater than that of MP (-1.49 vs. $-0.57 \mathrm{~g} / \mathrm{kg}$ per $\mathrm{g} / \mathrm{kg}$ of $\mathrm{DM}$ ).

\section{Effects of Other Dietary Factors on N Efficiency}

The effects of some other parameters in addition to PBV and MP intake are shown in Table 4. The model with PBV and MP intake as independent variables was improved when ME concentration was added in the model. However, it should be noted that the effect of ME was small in relation to the standard deviation of dietary ME concentration $(0.48 \mathrm{MJ} / \mathrm{kg}$ of $\mathrm{DM})$. Concentrations of the carbohydrate fractions had only minor effects on MNE. The quadratic models suggested that optimum NDF and NFC concentrations were 383 
Table 1. Feed and nutrient intake, diet composition, and production parameters of the dairy cow data used for the assessment of $\mathrm{N}$ utilization

\begin{tabular}{|c|c|c|c|c|c|}
\hline Item & $\mathrm{n}$ & Mean & $\mathrm{SD}$ & Minimum & Maximum \\
\hline \multicolumn{6}{|l|}{ DMI (kg/d) } \\
\hline Forage & 998 & 10.5 & 1.94 & 4.6 & 17.4 \\
\hline Concentrate & 998 & 7.4 & 2.33 & 0.0 & 18.4 \\
\hline Total & 998 & 17.9 & 2.82 & 9.9 & 25.2 \\
\hline Concentrate (kg/kg of DMI) & 998 & 0.41 & 0.100 & 0.00 & 0.80 \\
\hline \multicolumn{6}{|l|}{ Diet composition (g/kg of DM) } \\
\hline $\mathrm{CP}$ & 998 & 165 & 21.5 & 101 & 252 \\
\hline MP & 998 & 95 & 4.9 & 80 & 118 \\
\hline $\mathrm{PBV}^{1}$ & 998 & 8 & 17.3 & -51 & 82 \\
\hline RDP & 998 & 132 & 17.1 & 82 & 205 \\
\hline RUP & 998 & 33 & 6.1 & 17 & 59 \\
\hline $\mathrm{NDF}$ & 998 & 407 & 50.0 & 195 & 571 \\
\hline Starch & 998 & 147 & 60.0 & 0 & 364 \\
\hline \multicolumn{6}{|l|}{ Nutrient intake (g/d) } \\
\hline $\mathrm{CP}$ & 998 & 2,955 & 588 & 1,329 & 5,046 \\
\hline MP & 998 & 1,696 & 301 & 904 & 2,744 \\
\hline PBV & 998 & 136 & 298 & -805 & 1,616 \\
\hline $\mathrm{RDP}$ & 998 & 2,358 & 441 & 1,109 & 3,986 \\
\hline RUP & 998 & 597 & 163 & 199 & 1,275 \\
\hline Starch & 998 & 2,643 & 1,096 & 0 & 5,971 \\
\hline $\mathrm{NDF}$ & 998 & 7,282 & 1,353 & 3,621 & 11,129 \\
\hline $\mathrm{ME}(\mathrm{MJ} / \mathrm{d})$ & 998 & 206 & 33.8 & 114 & 298 \\
\hline \multicolumn{6}{|l|}{ Digestibility } \\
\hline OM & 509 & 0.736 & 0.038 & 0.621 & 0.830 \\
\hline Nitrogen & 483 & 0.691 & 0.041 & 0.542 & 0.819 \\
\hline $\mathrm{NDF}$ & 400 & 0.629 & 0.072 & 0.408 & 0.830 \\
\hline \multicolumn{6}{|l|}{ Production data } \\
\hline DIM & 998 & 103 & 30 & 38 & 226 \\
\hline Milk yield (kg/d) & 998 & 25.4 & 5.05 & 13.0 & 45.8 \\
\hline ECM yield $(\mathrm{kg} / \mathrm{d})$ & 998 & 26.1 & 5.14 & 12.8 & 42.1 \\
\hline \multicolumn{6}{|l|}{ Milk composition ( $\mathrm{g} / \mathrm{kg}$ ) } \\
\hline Fat & 998 & 42.8 & 3.96 & 31.9 & 55.0 \\
\hline Protein & 998 & 32.1 & 1.70 & 25.9 & 37.8 \\
\hline \multicolumn{6}{|l|}{ Milk component yield (g/d) } \\
\hline Fat & 998 & 1,081 & 217 & 479 & 1,671 \\
\hline Protein & 998 & 814 & 171 & 359 & 1,449 \\
\hline Milk N/N intake (g/kg) & 998 & 277 & 36.0 & 164 & 402 \\
\hline MUN (mg/100 mL) & 495 & 13.3 & 3.5 & 3.7 & 26.5 \\
\hline
\end{tabular}

${ }^{1} \mathrm{PBV}=$ rumen protein balance.

and $313 \mathrm{~g} / \mathrm{kg}$ of DM and optimum NFC/NDF was 0.99 (models not shown). However, the variation around the optimum was minimal.

Including silage LA, VFA, or total acid concentration $(\mathrm{n}=838)$ did not improve the models. Only VFA showed a trend $(P=0.07)$ toward reduced MNE with increased concentration, but the slope was small $(-0.14 \mathrm{~g} / \mathrm{kg}$ per $1 \mathrm{~g} / \mathrm{kg}$ of DM increase in silage VFA concentration). Increased soluble $\mathrm{N}$ concentration in silage $\mathrm{N}$ also tended $(P=0.08)$ to decrease MNE $(\mathrm{n}=537)$, but the effect can almost entirely be attributed to silage ammonia $\mathrm{N}(P$ $=0.01$ ), and the effect of soluble nonammonia $\mathrm{N}$ was nonsignificant $(P=0.31)$.

Addition of MUN ( $\mathrm{n}=495)$ with CP concentration or CP intake improved the model according to AIC, and the negative effects of MUN on MNE were highly significant $(P<0.001)$. However, the goodness of model was not improved when MUN was used together with PBV and MP concentrations or intakes.

\section{Analysis of Data Subsets}

Regression equations for MNE for the data subsets are shown in Table 5. Regression equations were rather similar irrespective of the method used to manipulate nutrient supply. Including the concentration of PBV always resulted in a better model compared with $\mathrm{CP}$ concentration according to AIC and, except for the concentrate supplementation studies, MP/CP ratio resulted in better models than PBV. Prediction error (RSME) was greatest in the concentrate level studies and the lowest in protein supplementation studies.

\section{Partition of $\mathrm{N}$}

Fecal N output was more closely associated with DM than with $\mathrm{N}$ intake (Table 6). The prediction was further improved when they both were used in the model. Regression coefficients indicated that fecal $\mathrm{N}$ output in- 
Table 2. Effects of nutrient intake on the efficiency of $\mathrm{N}$ utilization (milk N/N intake, $\mathrm{g} / \mathrm{kg}$ ) estimated by mixed model regression analysis $\left(\mathrm{Y}=\mathrm{A}+\mathrm{BX}_{1}+\mathrm{CX}_{2}\right)^{1}$

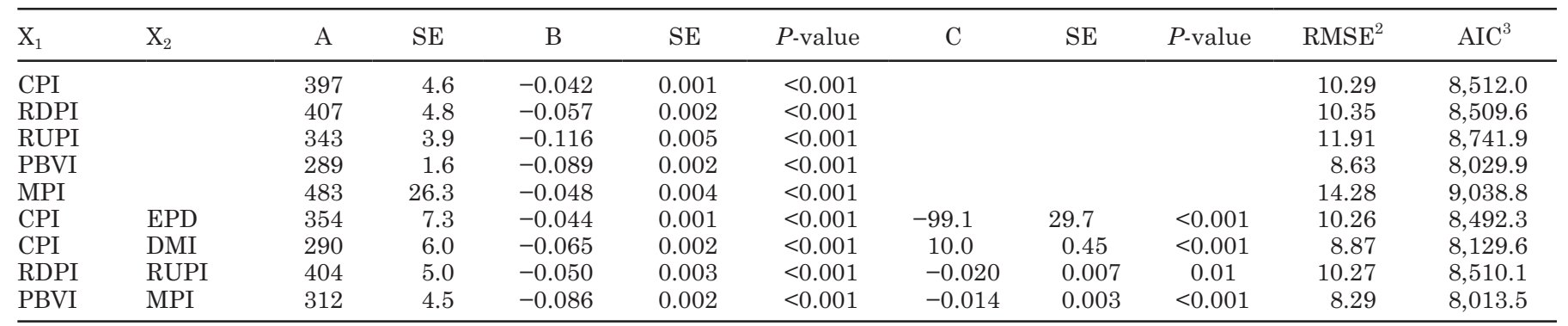

${ }^{1} \mathrm{CPI}=\mathrm{CP}$ intake $(\mathrm{g} / \mathrm{d}) ; \mathrm{RDPI}=\mathrm{RDP}$ intake $(\mathrm{g} / \mathrm{d}) ; \mathrm{RUPI}=\mathrm{RUP}$ intake $(\mathrm{g} / \mathrm{d}) ;$ PBVI = protein balance in the rumen $(\mathrm{g} / \mathrm{d}) ; \mathrm{MPI}=\mathrm{MP}$ intake $(\mathrm{g} / \mathrm{d})$; $\mathrm{EPD}=$ effective protein degradability $(\mathrm{g} / \mathrm{g}) ; \mathrm{DMI}=$ total DM intake $(\mathrm{kg} / \mathrm{d})$.

${ }^{2} \mathrm{RMSE}=$ residual mean square error.

${ }^{3} \mathrm{AIC}=$ Akaike's information criterion.

creased by $6.7 \mathrm{~g}$ per $1-\mathrm{kg}$ increase in DMI and that the true CP digestibility of the incremental CP was 0.91 . Fecal $\mathrm{N}$ output increased as the proportion of legume silage, mainly red clover, in forage increased. Urinary (unaccounted) $\mathrm{N}$ output increased with increased $\mathrm{N}$ intake, but at a constant $\mathrm{N}$ intake, DMI had a negative effect on urinary $\mathrm{N}$ output. The models were further improved by adding dietary ME concentration or milk yield as a third parameter in the model. Both fecal and urinary $\mathrm{N}$ output increased with milk yield, but the regression coefficient was much greater for urinary $\mathrm{N}$ compared with fecal $\mathrm{N}$ (11.4 vs. $5.5 \mathrm{~g}$ of $\mathrm{N} / \mathrm{kg}$ of milk). The proportion of urinary $\mathrm{N}$ of the total manure $\mathrm{N}$ was closely related to dietary $\mathrm{CP}$ concentration. In the data with MUN analysis ( $\mathrm{n}=348)$, MUN improved the urinary $\mathrm{N}$ output model compared with dietary $\mathrm{CP}$ alone (Table 6).

\section{DISCUSSION}

Compared with previous studies (Wilkerson et al., 1997; Castillo et al., 2000; Nennich et al., 2005; Yan et al., 2006), this study comprised several different aspects. First, it is based on a large treatment means data set rather than on individual cow data. Second, the present study used a more comprehensive analysis of nutrient supply including a detailed description of dietary protein and carbohydrate composition. Third, the relationships were examined when diet composition was manipulated using different nutritional strategies; for example, increased concentrate feeding, improved forage digestibility, and so on. In previous meta-analyses, only Nennich et al. (2005) used a mixed model procedure excluding the random study effects from the variation. As noted by St-Pierre (2001), using simple regression analysis can result in misinterpretation of the biological relationships.

\section{Effect of Milk Production}

The relationship between milk yield and $\mathrm{N}$ utilization was poor $\left(R^{2}=0.14\right.$; Figure 1$)$, although significant with the simple regression model. The $\mathrm{R}^{2}$ value increased
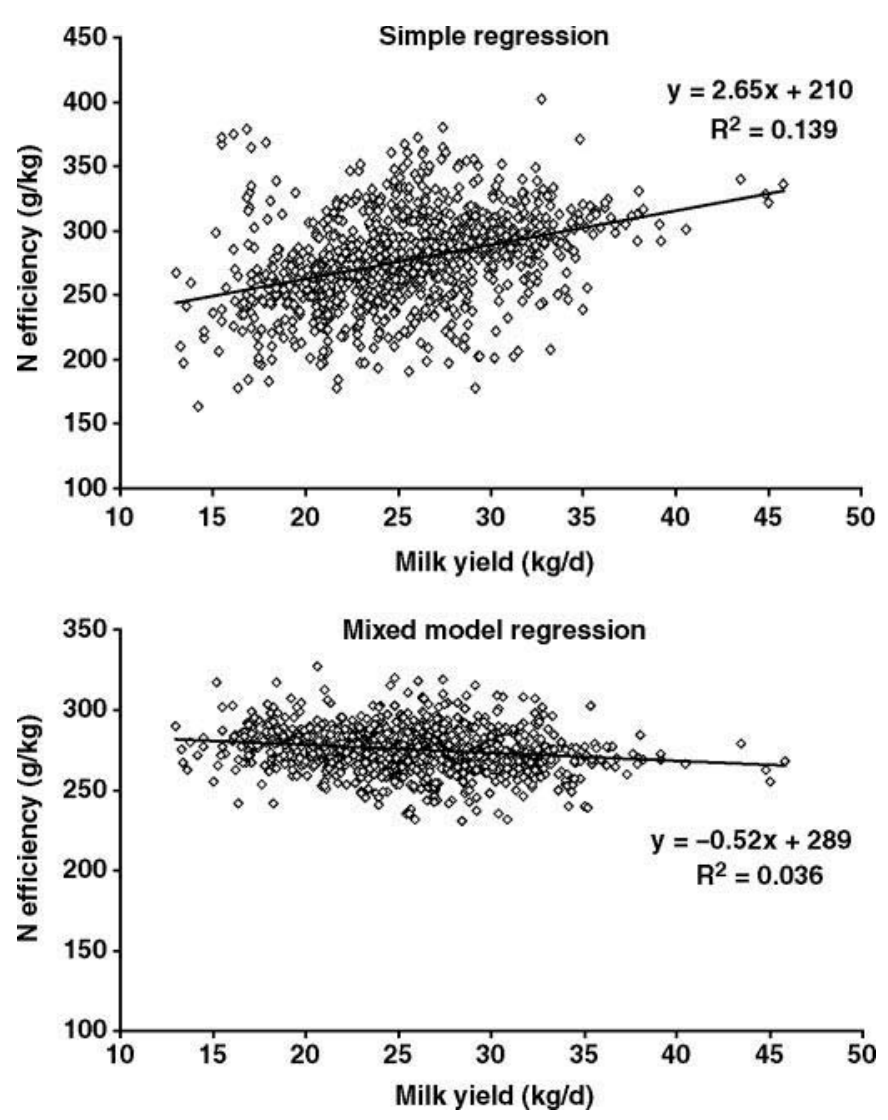

Figure 1. Relationship between milk yield and $\mathrm{N}$ efficiency analyzed by a simple (top) or mixed model regression (bottom). The values for mixed model data are adjusted for the random study effect. 
Table 3. Effects of dietary protein parameters on the efficiency of $\mathrm{N}$ utilization (milk N/N intake, g/kg) estimated by mixed model regression analysis $\left(\mathrm{Y}=\mathrm{A}+\mathrm{BX}_{1}+\mathrm{CX}_{2}\right)^{1}$

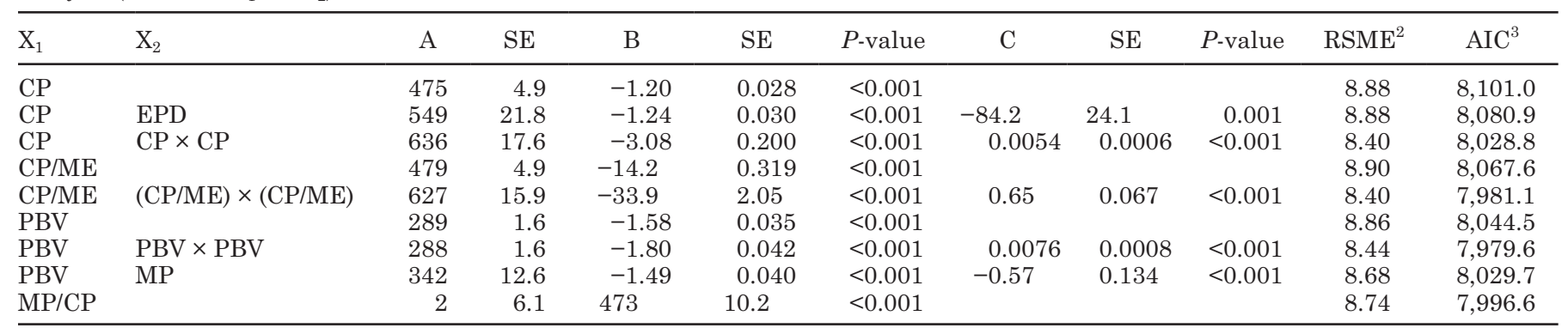

${ }^{1} \mathrm{CP}=$ crude protein $(\mathrm{g} / \mathrm{kg}$ of DM); EPD = effective protein degradability $(\mathrm{g} / \mathrm{g})$; CP/ME = CP/metabolizable energy $(\mathrm{g} / \mathrm{MJ}) ; \mathrm{PBV}=$ protein balance in the rumen $(\mathrm{g} / \mathrm{kg}$ of $\mathrm{DM}) ; \mathrm{MP}=$ metabolizable protein $(\mathrm{g} / \mathrm{kg}$ of $\mathrm{DM})$.

${ }^{2} \mathrm{RMSE}=$ residual mean square error.

${ }^{3} \mathrm{AIC}=$ Akaike's information criterion

Table 4. Effects of some dietary factors in addition to PBV and MP intake (g/d) on the efficiency of $\mathrm{N}$ utilization estimated by mixed model regression analysis $\left(\mathrm{Y}=\mathrm{A}+\mathrm{BX}_{1}+\mathrm{CX}_{2}+\mathrm{DX}_{3}+\mathrm{EX}_{4}\right)^{1}$

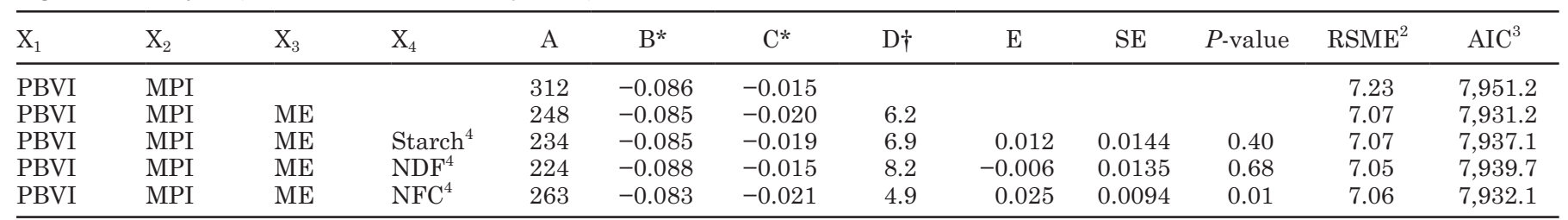

${ }^{1} \mathrm{PBVI}=$ protein balance in the rumen $(\mathrm{g} / \mathrm{d}) ; \mathrm{MPI}=\mathrm{MP}$ intake $(\mathrm{g} / \mathrm{d}) ; \mathrm{ME}=\mathrm{ME}$ concentration $(\mathrm{MJ} / \mathrm{kg}$ of DM); Starch, NDF (g/kg of DM); NFC $=$ nonfiber carbohydrates $(\mathrm{g} / \mathrm{kg}$ of $\mathrm{DM})$.

${ }^{2} \mathrm{RMSE}=$ residual mean square error.

${ }^{3} \mathrm{AIC}=$ Akaike's information criterion

${ }^{*} P<0.001 ; \dagger P<0.01$.

Table 5. Effects of protein parameters on the efficiency of $\mathrm{N}$ utilization when nutrient supply was manipulated by different strategies $(\mathrm{Y}=$ $\left.\mathrm{A}+\mathrm{BX}_{1}\right)^{1}$

\begin{tabular}{|c|c|c|c|c|c|c|c|c|}
\hline Item/parameter ${ }^{1}$ & $\mathrm{n}$ & $\mathrm{A}$ & SE & $\mathrm{B}$ & $\mathrm{SE}$ & $P$-value & $\mathrm{RSME}^{2}$ & $\mathrm{AIC}^{3}$ \\
\hline \multicolumn{9}{|l|}{ Concentrate level } \\
\hline $\mathrm{CP}$ & 217 & 492 & 17.4 & -1.29 & 0.105 & $<0.001$ & 8.26 & $1,866.4$ \\
\hline PBV & 217 & 293 & 2.0 & -2.07 & 0.130 & $<0.001$ & 7.94 & $1,803.6$ \\
\hline \multicolumn{9}{|c|}{ Protein supplementation } \\
\hline $\mathrm{CP}$ & 336 & 485 & 7.6 & -1.25 & 0.041 & $<0.001$ & 4.64 & $2,677.0$ \\
\hline PBV & 336 & 292 & 1.9 & -1.73 & 0.055 & $<0.001$ & 4.50 & $2,651.8$ \\
\hline $\mathrm{CP}$ & 81 & 462 & 19.2 & -1.16 & 0.103 & $<0.001$ & 6.25 & 694.0 \\
\hline PBV & 81 & 290 & 3.9 & -1.78 & 0.131 & $<0.001$ & 7.45 & 687.6 \\
\hline $\mathrm{MP} / \mathrm{CP}$ & 81 & -12 & 18.4 & 496 & 31.7 & $<0.001$ & 7.41 & 667.3 \\
\hline \multicolumn{9}{|c|}{ Silage fermentation quality } \\
\hline $\mathrm{CP}$ & 240 & 482 & 19.1 & -1.31 & 0.112 & $<0.001$ & 5.57 & $1,912.2$ \\
\hline PBV & 240 & 282 & 2.6 & -1.69 & 0.128 & $<0.001$ & 5.64 & $1,881.1$ \\
\hline $\mathrm{MP} / \mathrm{CP}$ & 240 & -30 & 17.6 & 520 & 32.1 & $<0.001$ & 5.60 & $1,850.7$ \\
\hline
\end{tabular}

${ }^{1} \mathrm{CP}=$ crude protein $(\mathrm{g} / \mathrm{kg}$ of DM); PBV = protein balance in the rumen $(\mathrm{g} / \mathrm{kg}$ of DM); MP = metabolizable protein $(\mathrm{g} / \mathrm{kg}$ of DM); MP/CP = metabolizable protein $(\mathrm{g} / \mathrm{kg}$ of $\mathrm{DM}) / \mathrm{CP}$.

${ }^{2} \mathrm{RMSE}=$ residual mean square error.

${ }^{3} \mathrm{AIC}=$ Akaike's information criterion. 
Table 6. Effects of dietary factors on fecal and urinary $\mathrm{N}$ (unaccounted $\mathrm{N}$ ) output $\left(\mathrm{Y}=\mathrm{A}+\mathrm{BX}_{1}+\mathrm{CX}_{2}+\mathrm{DX}_{3}\right)^{1}$

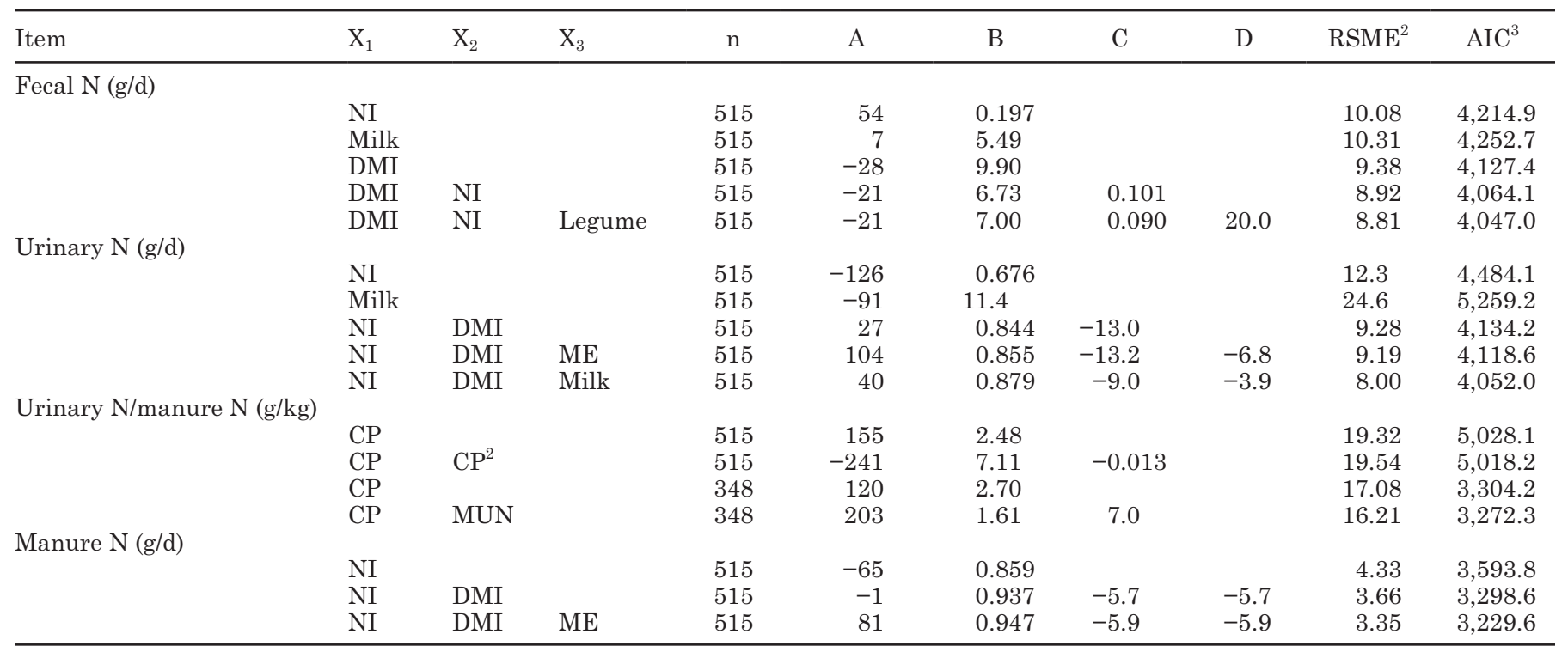

${ }^{1} \mathrm{NI}=\mathrm{N}$ intake $(\mathrm{g} / \mathrm{d}) ; \mathrm{DMI}=$ total DMI $(\mathrm{kg} / \mathrm{d}) ;$ Legume = proportion of legumes in the forage $(\mathrm{kg} / \mathrm{kg}) ; \mathrm{ME}=\mathrm{Dietary} \mathrm{ME}$ concentration $(\mathrm{MJ} / \mathrm{kg}$ of DM); Milk = milk production $(\mathrm{kg} / \mathrm{d}) ; \mathrm{CP}=$ dietary $\mathrm{CP}$ concentration $(\mathrm{g} / \mathrm{kg}) ; \mathrm{MUN}=$ milk urea $\mathrm{N}(\mathrm{mg} / 100 \mathrm{~mL})$.

${ }^{2} \mathrm{RMSE}=$ residual mean square error.

${ }^{3} \mathrm{AIC}=$ Akaike's information criterion

to 0.73 when dietary $\mathrm{CP}$ concentration was added into the model, which suggests that diet composition rather than production level is the main determinant of MNE in dairy cows. Based on regression coefficients of both simple and mixed bivariate models, $10 \mathrm{~g} / \mathrm{kg}$ of DM in dietary $\mathrm{CP}$ concentration and 1,200 to $1,300 \mathrm{~kg}$ in annual milk yield have similar effects on MNE. A recent study by Rechtenwald (2007) demonstrated that high $(>40 \mathrm{~kg} / \mathrm{d})$ milk yields can be obtained feeding a diet containing $140 \mathrm{~g}$ of $\mathrm{CP} / \mathrm{kg}$ of DM with only marginal production losses compared with a higher $\mathrm{CP}$ diet.

The different effect of milk yield on MNE when a random study effect was included in the statistical model is an example of the simple regression model leading to biological misinterpretation of the data (St-Pierre, 2001). When the random study effect was ignored, the positive relationship between milk yield and $\mathrm{N}$ efficiency arose evidently from the improved genetic milk yield potential during the time course of the present data (from 1979 to 2005) and from variation in DIM between the studies. Generally, it is assumed that MNE is improved with increased milk yield due to reduced maintenance costs (Tamminga, 1992). However, when the annual milk yield exceeds $7,500 \mathrm{~kg}$, only small progresses in MNE can be expected from increased milk yield (Tamminga, 1996). Van Bruchem et al. (1999) suggested that breeding more-productive dairy cattle is unlikely to be effective in reducing the $\mathrm{N}$ surpluses of milk production, because highly produc- tive dairy cows need diets with greater $\mathrm{CP}$ and energy concentrations. In a recent study based on field data, Virtanen and Nousiainen (2005) did not observe any relationship between milk yield and farm $\mathrm{N}$ efficiency.

In the present data, the marginal increase in milk protein yield within a study was $153 \mathrm{~g} / \mathrm{kg}$ increase in CP intake, which is markedly lower than the mean efficiency $(277 \mathrm{~g} / \mathrm{kg})$. Furthermore, increased milk yield within a study was associated with a much greater increase in urinary than fecal $\mathrm{N}$ output per kilogram of extra milk (Table 6). Because urinary $\mathrm{N}$ is more susceptible to leaching and volatilization than fecal $\mathrm{N}$, a shift toward greater urinary $\mathrm{N}$ excretion with increased milk yield is undesirable. However, the effects of increased milk yield on partitioning of manure $\mathrm{N}$ are equivocal. Broderick (2003) substituted a mixture of alfalfa and corn silage isonitrogenously with a mixture of high-moisture corn and soybean meal. In that study, increased milk yield with enhanced levels of highmoisture corn were associated with decreased urinary $\mathrm{N}$ output with no changes in fecal $\mathrm{N}$ output.

\section{Effect of Diet Composition (All Data)}

Reduced $\mathrm{N}$ efficiency with increased $\mathrm{N}$ intake (Table 2 ) is consistent with the observations of Castillo et al. (2000), who reported decreases in MNE especially with daily $\mathrm{N}$ intakes exceeding $400 \mathrm{~g}$. Including EPD in the $\mathrm{CP}$ intake model or dividing $\mathrm{CP}$ intake into RDP and 
RUP intake did not markedly improve the goodness of fit of the model according to AIC, which suggests that estimates of protein degradability may not be accurate. It is also possible that expected benefits from the reduced degradability were not fully realized because of reduced microbial protein synthesis (Santos et al., 1998; Ipharraguerre and Clark, 2005), lower RUP digestibility of treated protein supplements (Rinne et al., 1999), or nonideal AA composition of RUP.

The better predictions with PBV intake could be expected, because it is an estimate of excess rumen degradable $\mathrm{N}$, which is absorbed as ammonia from the rumen (Madsen, 1985). In addition to degradability, PBV takes into account the energy supply for microbial protein synthesis. Prediction was further improved including MP intake in the model, but the negative coefficient for MP intake was proportionally only 0.16 of that for PBV. This suggests that if the MP supply could be increased with minimal increases in PBV, MNE could be improved without compromising milk yield. Børsting et al. (2003) showed that positive PBV had only minor effects on milk protein yield, and they concluded that maximal yield and high MNE could be reached at a rumen protein balance close to zero.

Previously, MNE (Castillo et al., 2000) and manure $\mathrm{N}$ output (Kebreab et al., 2001; Yan et al., 2006) have been predicted as a function of $\mathrm{N}$ intake. In the present study, using DMI with CP intake in the model developed a more precise prediction than $\mathrm{CP}$ intake alone. It should also be noted that these variables had a different coefficients (Table 2). When the increase in CP intake is due to greater DMI, the supply of fermentable $\mathrm{OM}$ also increases, allowing a more efficient capture of $\mathrm{RDP}$ by rumen microbes and utilization of absorbed AA for milk protein synthesis

Dietary CP concentration explained the variation in MNE better than did $\mathrm{CP}$ intake. The ratio $\mathrm{CP} / \mathrm{ME}$ resulted in a more precise model than CP (Table 3), probably because the supply of fermentable substrate for rumen microbes increased with ME. However, PBV (which takes into account both ruminal degradability and energy supply for microbial protein synthesis) was better than $\mathrm{CP}$ or $\mathrm{CP} / \mathrm{ME}$. The ratio $\mathrm{MP} / \mathrm{CP}$ was the best single predictor of $\mathrm{N}$ efficiency (Table 3). This parameter takes into account fermentable energy supply for rumen microbes and protein degradability in addition to $\mathrm{CP}$ concentration. In a bivariate model with $\mathrm{PBV}$ and MP as independent variables, the slope was greater for PBV than for MP (-1.57 vs. -0.49$)$. The negative slope indicates that $\mathrm{N}$ efficiency is also decreased by overfeeding MP, even without an increase in rumen $\mathrm{N}$ losses.

The diets of the present study were based largely on grass silage as forage. Soluble sugars of grass are converted to LA and VFA through the action of anaerobic bacteria in the silo, and grass CP is extensively degraded to NPN. Silage CP is rapidly and extensively fermented to ammonia in the rumen, and therefore, synchronizing energy and $\mathrm{N}$ release in the rumen should improve MNE (Sinclair et al., 1993). However, this study did not provide support for benefits from including more starch or NFC in the diet. It is possible that the opportunity to improve MNE with increased starch or NFC supplementation was not realized because of limits imposed by excess acid production and depressed $\mathrm{pH}$ in the rumen. In other studies, some positive responses to improved synchronization of energy and $\mathrm{N}$ in terms of rumen microbial $\mathrm{N}$ production or improved milk production have been reported (see Castillo et al., 2000). On the other hand, the review of Chamberlain and Choung (1995) suggests that no benefits of synchronization (timing the energy and $\mathrm{N}$ release) can be expected.

Fermentation of sugars to LA and VFA in the silo decreases microbial $\mathrm{N}$ synthesis in the rumen (Jaakkola et al., 2006), but the extent of silage fermentation in the silo did not influence MNE in the present meta-analysis. Increased blood glucose supply from the fermentation of silage LA to propionic acid could counterbalance the reduced microbial $\mathrm{N}$ synthesis (Harrison et al., 2003); and MNE is not reduced when extensively fermented silages are fed.

\section{Analysis of Data Subsets}

The effects of dietary $\mathrm{CP}$ and PBV concentrations or the ratio of $\mathrm{MP} / \mathrm{CP}$ on the efficiency of $\mathrm{N}$ utilization were similar regardless of how the diet composition was changed (Table 5). This demonstrated that increased dietary $\mathrm{CP}$ concentration uniformly decreases MNE. The effects of the level of concentrate supplementation on MNE depend on the changes in dietary CP and especially in PBV concentration. When high protein forages are supplemented with increasing amounts of low $\mathrm{CP}$ concentrates, MNE improves, whereas the reverse is true when low CP silages are supplemented with increasing amounts of high CP concentrates. The slope of concentrate DMI on MNE was $3.8,0.1$, and $-3.7 \mathrm{~g} / \mathrm{kg}$ for concentrates containing $<150,150$ to 220 , or $>220 \mathrm{~g}$ of $\mathrm{CP} / \mathrm{kg}$ of $\mathrm{DM}$, respectively.

Attempts to improve MNE by feeding more concentrates with grass silage-based diets have not been very successful, especially if high CP concentrates are fed. This is at least partly because the marginal production responses of 0.09 to $0.10 \mathrm{~kg}$ of ECM or milk per MJ of ME (Thomas, 1980; Huhtanen, 1998) to extra ME from increased concentrate feeding are relatively small compared with the expected response of 0.194 (MTT, 
2006). As discussed previously, optimum dietary NDF and NFC concentrations suggest that $\mathrm{N}$ efficiency is, in most cases, maximized using moderate levels ( 0.35 to 0.50) of concentrates.

Reducing the ruminal degradability of protein supplements has been suggested as a strategy to improve MNE (Tamminga, 1992; Kirchgessner et al., 1994). However, in protein supplementation studies, MNE only tended $(P=0.08)$ to improve with reduced EPD when it was used with $\mathrm{CP}$ concentration in the model (data not shown). This is surprising, because different protein supplements ranging from urea to fish meal were used. Different explanations can be suggested for this. First, the current methods and protein evaluation models may overestimate the range in protein degradability. Indeed, using a constant degradability for all feeds resulted in better predictions of milk protein yield responses compared with using in situ determined values (Tuori et al., 1998) or tabulated values (Schwab et al., 2005). Second, a review of large number of studies by Santos et al. (1998) and Ipharraguerre and Clark (2005) suggested that increased supply of RUP often resulted in a reduced supply of rumen microbial protein. More specifically, with grass silage-based diets, heat-moisture-treated rapeseed cake did not elicit milk or milk protein yield responses compared with untreated rapeseed meal despite the fact that graded doses of each supplement produced substantial production responses (Rinne et al., 1999). The true digestibility of supplemental protein derived from heat-treated rapeseed expeller was significantly lower than that of solvent-extracted rapeseed meal (Rinne et al., 1999) or soybean meal (Shingfield et al., 2003). Kebreab et al. (2001) also reported greater fecal $\mathrm{N}$ output with decreased protein degradability, but urinary $\mathrm{N}$ output was decreased.

\section{Partitioning of Dietary N}

The relationship between $\mathrm{N}$ intake and fecal $\mathrm{N}$ output was in agreement with the equation presented by Castillo et al. (2000) based on individual cow data. Fecal $\mathrm{N}$ output was predicted more precisely using a model with $\mathrm{DM}$ and $\mathrm{N}$ intakes as independent variables rather than $\mathrm{N}$ intake alone. The bivariate model better takes into account the origin of fecal $\mathrm{N}$ losses, which are derived from excretion of undigested feed N, undigested microbial N, and endogenous N. Metabolic and endogenous $\mathrm{N}$, which has a major contribution to fecal N, is related to DMI (Van Soest, 1994), whereas undigested feed $\mathrm{N}$ is related to $\mathrm{N}$ intake.

The negative intercept of the bivariate model, which is biologically impossible, suggests a curvilinear relationship between DMI and metabolic and endogenous fecal N. Indeed, a quadratic model solved the intercept problem, but the standard errors of parameters were high. Another alternative to predict fecal $\mathrm{N}$ output is to use the Lucas test and include DMI in the model to predict fecal $\mathrm{N}$ output per kilogram of DMI. For a cow consuming $20 \mathrm{~kg}$ of $\mathrm{DM} / \mathrm{d}$ ( $160 \mathrm{~g}$ of $\mathrm{CP} / \mathrm{kg}$ of $\mathrm{DM})$, the bivariate model (N intake and DMI) predicted fecal $\mathrm{N}$ output of $165 \mathrm{~g} / \mathrm{d}$, of which $69 \%$ was of metabolic and endogenous origin and $31 \%$ undigested feed $\mathrm{N}$.

As discussed by Tamminga (1992), possibilities to improve MNE by improving $\mathrm{N}$ digestibility seem to be limited because the true digestibility of dietary $\mathrm{N}$ is rather constant and high. Endogenous $\mathrm{N}$ losses seem mainly to be related to DM passing the small intestine and undigested DM or OM excreted in feces (Tamminga, 1992). However, addition of predicted diet digestibility in the model had no influence on fecal $\mathrm{N}$ output in the present study.

Accurate prediction of urinary $\mathrm{N}$ output is more difficult due to errors in $\mathrm{N}$ balance measurements (Spanghero and Kowalski, 1997; Reynolds and Kristensen, 2007). Typically, measured $\mathrm{N}$ balances in ruminants are greater than expected, based on the changes in body mass or measured protein accretion (Reynolds and Kristensen, 2007). In the present study, the urinary $\mathrm{N}$ output was estimated as $\mathrm{N}$ intake - (milk $\mathrm{N}$ + fecal $\mathrm{N}$ ) and manure $\mathrm{N}$ as $\mathrm{N}$ intake - milk $\mathrm{N}$; that is, assuming zero $\mathrm{N}$ balance. Although true $\mathrm{N}$ balance can be substantially positive or negative in short-term measurements, it cannot be markedly different from zero during the whole lactation. Live weight gain of 50 $\mathrm{kg}$ in a year corresponds to a daily average $\mathrm{N}$ retention of $3.5 \mathrm{~g} / \mathrm{d}$ assuming $160 \mathrm{~g}$ of $\mathrm{CP} / \mathrm{kg}$ of live weight gain. This value is markedly lower than the mean measured values of 38.8 (SD: 52.2) and 26.0 (SD: 35.0) g/d in the data sets of Spanghero and Kowalski (1997) and Yan et al. (2006), respectively. These values would correspond to 300 to $450 \mathrm{~kg}$ of live weight gain during a 305 -d lactation.

The minor losses in hair and scurf are usually not accounted for in $\mathrm{N}$ balance studies in dairy cows. This, together with some gaseous losses, nitrate formation, and fecal ammonia $\mathrm{N}$ losses will result in slight overestimation of $\mathrm{N}$ balance. The proportion of ammonia $\mathrm{N}$ in fecal $\mathrm{N}$ increased from 4 to $7 \%$ with increased dietary CP concentration in the diets of growing heifers (Marini and Van Amburgh, 2005). This fraction is lost unless fecal samples are acidified or analyzed as fresh. In the present data the possible loss of fecal ammonia $\mathrm{N}$ was accounted for in urinary $\mathrm{N}$. Abrupt changes in $\mathrm{N}$ intake can alter the size of labile N pools (Reynolds and Kristensen, 2007), which may lead to errors in estimating urinary and manure $\mathrm{N}$ output in short-term $\mathrm{N}$ balance measurements. In relation to urinary (unac- 
counted) N output (206 g/d; SD: 57.8) the error related to realistic $\mathrm{N}$ retention during the whole lactation is $<2 \%$. Van Horn et al. (1994) stated that manure $\mathrm{N}$ can be estimated as a difference between $\mathrm{N}$ intake and $\mathrm{N}$ output in milk.

Urinary $\mathrm{N}$ originates from various sources such as rumen loss, metabolic losses in the gut, incorporation of dietary protein to microbial nucleic acids, maintenance requirement, and losses because of inefficient conversion of absorbed amino acids to milk protein (Tamminga, 1992). In particular, rumen losses and losses due to inefficient conversion of amino acids to milk protein can be reduced by manipulating diet composition. The bivariate model with $\mathrm{N}$ intake and DMI as independent variables suggested that proportionally $84.4 \%$ of the incremental $\mathrm{N}$ was excreted in urine (Table 6).

Similarly as with fecal N, including DMI in the model with $\mathrm{N}$ intake improved the precision of urinary $\mathrm{N}$ output prediction. The much greater coefficient for $\mathrm{N}$ intake in the bivariate model is related to the fact that increased $\mathrm{N}$ intake at a constant DMI (i.e., increased $\mathrm{CP}$ concentration) increases both rumen $\mathrm{N}$ losses from increased RDP supply and metabolic $\mathrm{N}$ losses from increased MP supply. In the present study, total manure $\mathrm{N}$ output was predicted more accurately compared with the studies of Kebreab et al. (2001) and Yan et al. (2006), in part because zero $\mathrm{N}$ retention rather than determined urinary output was used, and in part because treatment mean rather than individual cow data were used. Manure N output increased much less with increasing $\mathrm{N}$ intake in their studies (0.62 and 0.72) compared with the present study (0.86).

\section{CONCLUSIONS}

Dietary concentrations of CP and PBV were strongly and negatively related to MNE. The model parameters were consistent for different data subsets, indicating that the relationship between dietary CP or PBV concentration and MNE were consistent. Dietary CP concentration predicted $\mathrm{N}$ efficiency better than $\mathrm{CP}$ intake, because increased $\mathrm{CP}$ intake derived from increased concentration or DMI has contrary effects on ruminal and metabolic $\mathrm{N}$ losses. The models based on MP and PBV predicted MNE better than those based on $\mathrm{CP}$ alone. Fecal, urinary, and total manure $\mathrm{N}$ outputs were predicted more precisely using a bivariate regression model with $\mathrm{DM}$ and $\mathrm{N}$ intakes as variables compared with the $\mathrm{N}$ intake alone. Nitrogen efficiency can be improved and manure $\mathrm{N}$ (especially urinary $\mathrm{N}$ ) output reduced by decreasing dietary $\mathrm{CP}$ and PBV concentrations. Decreasing dietary CP concentration will also decrease the proportion of less desirable urinary $\mathrm{N}$ in manure N. Feeding strategies that increase milk yield do not unequivocally improve $\mathrm{N}$ efficiency, especially if milk yield responses are derived from increased dietary $\mathrm{CP}$ concentration,

\section{REFERENCES}

Børsting, C. F., T. Kristensen, L. Misciattelli, T. Hvelplund, and M. R. Weisbjerg. 2003. Reducing nitrogen surplus from dairy farms. Effects of feeding and management. Livest. Prod. Sci. 83:165178.

Broderick, G. A. 2003. Effects of varying dietary protein and energy levels on the production of lactating dairy cows. J. Dairy Sci. 86:1370-1381.

Castillo, A. R., E. Kebreab, D. E. Beever, and J. France. 2000. A review of efficiency of nitrogen utilisation in lactating dairy cows and its relationship with environmental pollution. J. Anim. Feed Sci. 9:1-32.

Chamberlain, D. G., and J.-J. Choung. 1995. The importance of rate or ruminal fermentation of energy sources in diets for dairy cows. Pages 3-27 in Recent Advances in Animal Nutrition. P. C. Garnsworthy, and D. J. A. Cole, ed. Butterworths, London, UK.

Groot, C. J., W. A. H. Rossing, and E. A. Lantinga. 2006. Evolution of farm management, nitrogen efficiency and economic performance on Dutch dairy farms reducing external inputs. Livest. Sci. 100:99-110.

Harrison, J., P. Huhtanen, and M. Collins. 2003. Perennial grasses. Pages 665-747 in Silage Science and Technology. D. R. Buxton, R. E. Muck, and J. H. Harrison, ed. American Society of Agronomy, Madison, WI.

Huhtanen, P. 1998. Supply of nutrients and productive responses in dairy cows given diets based on restrictively fermented grass silage. Agric. Food Sci. Finl. 7:219-250.

Ipharraguerre, I. P., and J. H. Clark. 2005. Impact of the source and amount of crude protein on the intestinal supply of nitrogen fractions and performance of dairy cows. J. Dairy Sci. 88(E Suppl.):E22-E37.

Jaakkola, S., V. Kaunisto, and P. Huhtanen. 2006. VFA proportions and microbial protein synthesis in the rumen of cattle receiving grass silage ensiled with different rates of formic acid. Grass Forage Sci. 61:282-292.

Kebreab, E. J., J. France, D. E. Beever, and A. R. Castillo. 2001. Nitrogen pollution by dairy cows and its mitigation by dietary manipulation. Nutr. Cycl. Agroecosyst. 60:275-285.

Kirchgessner, M., W. Windisch, and F. X. Roth. 1994. The efficiency of nitrogen conversion in animal nutrition. Nova Acta Leopold. 70:393-412.

Littell, R. C., G. A. Milliken, W. W. Stroup, and R. D. Wolfinger. 1996. SAS® System for Mixed Models. SAS Institute Inc., Cary, NC.

Madsen, J. 1985. The basis of proposed Nordic protein evaluation system for ruminants. The AAT-PBV system. Acta Agric. Scand. 25(Suppl.):9-20.

Marini, J. C., and M. E. Van Amburgh. 2005. Partition of nitrogen excretion in urine and the feces of Holstein replacement heifers. J. Dairy Sci. 88:1778-1784.

MTT. 2006. Rehutaulukot ja ruokintasuositukset (Feed Tables and Feeding Recommendations). Agrifood Research Finland. http:// www.mtt.fi/rehutaulukot.

Nennich, T. D., J. H. Harrison, L. M. VanWieringen, D. Meyer, A. J. Heinrichs, W. P. Weiss, N. R. St-Pierre, R. L. Kincaid, D. L. Davidson, and E. Block. 2005. Prediction manure and nutrient excretion from dairy cattle. J. Dairy Sci. 88:3721-3733.

Nousiainen, J., M. Rinne, M. Hellämäki, and P. Huhtanen. 2003. Prediction of the digestibility of the primary growth of grass silages harvested at different stages of maturity from chemical composition and pepsin-cellulase solubility. Anim. Feed Sci. Technol. 103:97-111.

Nousiainen, J., K. J. Shingfield, and P. Huhtanen. 2004. Evaluation of milk urea concentration as a diagnostic of protein feeding. J. Dairy Sci. 87:386-398. 
Rechtenwald, E. B. 2007. Effect of feeding corn silage based diets predicted to be deficient in either ruminal nitrogen or metabolizable protein on nitrogen utilization and efficiency of use in lactating cows. MS Thesis. Cornell University, Ithaca, NY.

Reynolds, C. K., and N. B. Kristensen 2008. Nitrogen recycling through the gut and the nitrogen economy of ruminants; an asynchronous symbiosis. J. Anim. Sci. 86(E Suppl.):E293E305.

Rinne, M., S. Jaakkola, T. Varvikko, and P. Huhtanen. 1999. Effects of the type and amount of rapeseed feed on milk production. Acta Agric. Scand., Sect. A Anim. Sci. 49:137-148.

Santos, F. A. P., J. E. P. Santos, C. B. Theurer, and J. T. Huber. 1998. Effects of rumen undegradable protein on dairy cow performance: A 12-year literature review. J. Dairy Sci. 81:3182-3213.

Schwab, C. G., P. Huhtanen, C. W. Hunt, and T. Hvelplund. 2005. Nitrogen requirements of cattle. Pages 13-70 in Nitrogen and Phosphorus Nutrition of Cattle-Reducing the Environmental Impact of Cattle Operations. E. Pfeffer and A. N. Hristov, ed. CABI Publishing, Wallingford, UK.

Shingfield, K. J., A. Vanhatalo, and P. Huhtanen. 2003. Comparison of heat-treated rapeseed expeller and solvent-extracted soyabean meal protein supplements for dairy cows given grass silagebased diets. Anim. Sci. 77:305-317.

Sinclair, L. A., P. C. Garnsworthy, J. R. Newbold, and P. J. Buttery. 1993. Effect of synchronisation of the rate of dietary energy and nitrogen release on rumen fermentation and microbial protein synthesis in sheep. J. Agric. Sci. Camb. 120:251-263.

Spanghero, M., and Z. M. Kowalski. 1997. Critical analyses of N balance experiments with lactating dairy cows. Livest. Prod. Sci. 52:113-122.

St-Pierre, N. R. 2001. Integrating quantitative findings from multiple studies using mixed model methodology. J. Dairy Sci. 84:741755 .

Tamminga, S. 1992. Nutrition management of dairy cows as a contribution to pollution control. J. Dairy Sci. 75:345-357.

Tamminga, S. 1996. A review on environmental impacts of nutritional strategies of ruminants. J. Anim. Sci. 74:3122-3124.
Thomas, C. 1980. Conserved forages. Pages 8.1-8.14 in Feeding Strategies for Dairy Cows. W. H. Broster, C. L. Johnson, and C. J. Taylor, ed. Agricultural Research Council, London, UK.

Tilley, J. M. A., and R. A. Terry. 1963. A two-stage technique for in vitro digestion of forage crops. Br. J. Grassl. Soc. 18:104-111.

Tuori, M., K. Kaustell, and P. Huhtanen. 1998. Comparison of the protein evaluation systems of feed for dairy cows. Livest. Prod. Sci. 55:33-46.

Van Bruchem, J., H. Schiere, and H. Van Keulen. 1999. Dairy farming in the Netherlands in transition towards more efficient use of nutrients. Livest. Prod. Sci. 61:145-153.

Van Horn, H. H., A. C. Wilkie, W. J. Powers, and R. A. Norstedt. 1994. Components of dairy manure management systems. J. Dairy Sci. 77:2008-2030.

Van Keulen, H., H. G. Van der Meer, and I. J. M. De Boer. 1996 In: Nutrient balances of livestock production systems in The Netherlands. Pages 3-18 in Utilization of Local Feed Resources by Dairy Cattle-Perspectives of Environmentally Balanced Production Systems. A. F. Groen, and J. van Bruchem, ed. EAAP Publication no. 84, Wageningen Pers., Wageningen, the Netherlands.

Van Keulen, J., and B. A. Young. 1977. Acid insoluble ash as a natural marker for digestibility studies. J. Anim. Sci. 44:282-287.

Van Soest, P. J. 1994. Nutritional Ecology of the Ruminant. Cornell University Press, Ithaca, NY.

Virtanen, H., and J. Nousiainen. 2005. Nitrogen and phosphorus balances on Finnish Dairy Farms. Agric. Food Sci. 14:166-180.

Wilkerson, V. A., D. R. Mertens, and D. P. Casper. 1997. Prediction of excretion of manure and nitrogen by Holstein dairy cattle. J. Dairy Sci. 80:3193-3204.

Yan, T., J. P. Frost, R. E. Agnew, R. C. Binnie, and C. S. Mayne. 2006. Relationship among manure nitrogen output and dietary and animal factors in lactating dairy cows. J. Dairy Sci. 89:39813991. 